\title{
TRAINING OF AFRICAN NURSES IN NYASALAND (MALAWI) FROM 1889 TO 1927
}

\author{
Joyce Smit
}

\section{Summary}

When the first pioneer missionaries arrived in Nvasaland during 1860 there was no educational system in operation according to Western standards. The training of nurses (male and female) therefore evolved as the educational system developed.

Before 1900 the training of nurses was done independently by each mission. only providing staff for their local clinics and hospitals. Although the missions worked in different areas of the country, they realised from the start that they should co-operate to achieve results in the medical, educational and technical fields of their work. The Protestant Missions therefore held a series of general missionary conferences where they discussed the different aspects of their work. Six such conferences were held.

During the second conference in 1904, an educational code was drawn up and accepted by the missions of the whole Protectorate. During this conference three standards of training was suggested namely that of dressers. hospital attendants and medical assistants. The different syllabuses were discussed. On the suggestion of the Commissioner of the Protectorate, a Medical Board was formed during 1905, to plan for training courses and arrange for examinations. This Board consisted of government and mission representatives.

During 1909 the medical courses became more refined. The government did not take part in the training of nurses but was willing to employ as many nurses as the missions could manage to train.

The education system began to develop steadily but then in 19/4-1918 war came which caused much disruption. The years of 1919 to 1925 were years of recovery. The education was again stimulated by the visit of the Phelps-Stokes Commission during 1924 which recommended a policy of cooperation in education between Government and Missions.

A Department of Education was formed during 1926 and it was decided that vocational schools, which included schools where medical assistants and dispensers were trained, should be under the control of the Department. During 1926 a Medical Council was formed which laid down the standards of courses and examinations of medical assistants. Section 18 of the Medical Practitioners and Dentist's Ordinance of 1926 also made provision for a subregister to be kept for the registration of medical assistants. This gave well trained Africans standing in their own country and was gladly welcomed by the missions.

The African nurses were of sound Christian character and respected by all the peoples in the country. The missionaries felt that the training of medical personnel was one of their best contributions to the medical services and to the population of the country.

\section{Opsomming}

Met die aankoms van die pioniersendelinge in Nyasaland (Malawi) in 1860, was daar nog geen opvoedkundige stelsel volgens, Westerse standaard. in werking nie. Die opleiding van verpleegsters (manlik en vroulik) het dus saam met die onderwysstelsel ontwikkel.

Voor 1900 het elke sendinggroep verpleegsters slegs vir hul eie behoeftes in hul klinieke en hospitale opgelei. Die sendinggenootskappe het egter van die begin af die nadeel hiervan hesef en vanaf 1900 is in gesamentlike poging aangewend om opleiding op mediese. ondern'ys-en tegniese gebiede te standaardiseer.

Gedurende 1904 is 'n opvoedkundige kode saamgestel en deur al die Protestantse Sendinggroepe in die Protektoraat aanvaar. Drie tipes van verpleegopleiding is voorgestel naamlik die van wondverbinders, hospilaalassistente en mediese assistente. In 1905 is 'n Mediese Raad saamgestel met verteenwoordigers van die regering en sendinggenootskappe om standaarde van verpleegopleiding en eksaminering te bepaal.

Die regering het nie deelgeneem in verpleegopleiding nie, maar was gretig om soveel as moontlik van die verpleegsters in diens te neem wat deur die sendinggenootskappe opgelei is.

Die onderwysstelsel het voortdurend ontwikkel, maar die oorlog van 19141918 het haie ontwrigting veroorsaak. Die jare 1919 tot 1925 was jare van herstel. Gedurende 1924 is die onderwys weer gestimuleer deur die besoek van die Phelps-Stokes kommissie. Die kommissie het voorgestel dat daar nouer samewerking tussen die sendinggenootskappe en regering op onderwys gebied moes plaasvind. Gedurende 1926 is dan ook 'n Departement van Onderwys gevorm. Die beroepskole, waaronder die opleidingskole van mediese assistente en aptekers geressorteer het, het dan ook onder die Departement van Onderwys se jurisdiksie gekom.

Gedurende 1926 is daar ook in

Mediese Raad gevorm wat die standaarde van kursusse en eksamens bepaal het. Afdeling 18 van die Ordonnansie op Mediese Praktisyns en Tandarste het voorsiening gemaak vir 'n sub-register waaronder mediese assistente kon registreer. Die sendinggenootskappe was verheug oor die besluit omdat dit die goed-opgeleide mediese assistente status onder hul eie mense en in hul eie land gegee het.

Die verpleegsters was van goeie christelike karakter en gerespekteer deur al die mense in die land. Die sendelinge was van mening dat die opleiding van mediese personeel een van hul beste bydraes vir die mediese dienste en mense van die land was.

\section{INTRODUCTION}

This abstract forms part of a M. thesis in nursing named: "The role of the Dutch Reformed Church Mission in the development of nursing in Nyasaland (Malawi) from 1860 to $1927^{\prime \prime}$, with studyleaders Prof. I.M. Hofmeyr and Prof. D.J. Kotzè.

When the first pioneer Missionaries arrived in Nyasaland during 1860 there was no educational system according to Western standards in operation. The Missionaries immediately started with a village school system and education developed hand in hand with the spreading of the Gospel. The training of nurses was dependent on the educational standard of the African people. The training of nurses will therefore be discussed under the different periods as the educational system developed.

\section{THE PERIOD 1889 - 1900}

In 1895 the first girls boarding school (home) under Miss Martha Murray was opened.' These boarding schools played a significant part in preparing the girls to a 
high enough educational level to be accepted for nurse training in years to come.

Before 1900 the training of nurses was done independently by each mission, only providing nursing staff for their local clinics and hospitals. The two Scottish Missions took the lead in nurse training and by 1900 both Livingstonia and Blantyre Missions were training hospital assistants and dressers. During 1894 the Overtoun Institute was established at Khondowe and the D.R.C. Mission, then still part of the Livingstonia Mission, sent their students to the Institution to be trained as teachers and evangelists.

The D.R.C. Mission had lagged behind in training nurses not only because they arrived in the country 28 years later than the Livingstonia Mission but also because they had to wait for 11 years before the first medical doctor was appointed during 1900 and another three years before a hospital was established. For this reason the D.R.C. Mission did not take part in training during this period as it was a od of establishment.

THE PERIOD 1901 - 1925

During 1900 the first of six general mission conferences was held at Livingstonia to discuss the various aspects of mission work and to try to obtain co-ordination with regard to training, education and medical work.

Inspired by the conference the D.R.C. Mission opened a training school at Mvera during 1902. This institution did not make provision for a training course for nurses, like the Scottish Missions, but only trained teachers and evangelists. Nurse training was only started during 1903, after the establishment of the hospital at Mvera.

In October 1904, a second General Mission Conference was held in Blantyre for further consultation and planning. An educational code was drawn up for the use of all the missionaries and an Education Prd appointed. ${ }^{2}$

his Board met in May 1905 and drew up a revised educational code for the missions of the whole protectorate. The code was described as follows: "In this provision has been made for education of every possible grade, from the primary village school in the village hut to the Central Training Institution Educational, Commercial, Technical, Medical and Theological - which will be affiliated to its fellows as the Central African United Educational Institutions finally to merge in a Central African College and University."

"This scheme and code has been adopted by all the Missions of the Protectorate with one exception, and on the strength of this unity, an application had been made by the Missions jointly to His Majesty's Government for assistance in the form of a grant-in-aid."'

(From 1908 to 1918 an annual grant of fl 000 was made by Government in aid of education. From 1918 to 1926 the grant was increased to $£ 2000$ a year, divided proportionately among the missions in accordance with the educational work performed by them.) ${ }^{4}$

During this second conference, the training of African nurses (men and women) was discussed. Dr. Caverhill of the Blantyre Mission, who by then had gained experience at his Mission of the training of African men as nurses, suggested three standards of training:

1. Class I or "Dressers", men who were trained merely in the dressing of wounds and the handing out of stock medicines. Their training would last about six months and they would be trained for two purposes. The first would be in the case of teachers and evangelists who were put in charge of sub-stations, and who had been unable to take a fuller course. This would enable them to deal with the simpler cases that came to their notice, and would enhance their influence in their district. The other purpose of this short course would be to train men sent in by neighbouring planters, where such exist who would wish to have a man on their estate who, while being eligible for other work, would be able to treat ulcers among the Africans on his estate. Much sickness could be avoided by treating many little scratches properly from the beginning.

For the training of Dressers no special course needed to be laid down, as all would be taught practically, for they would learn most from the boys they were working along side of, coupled with the practical work of giving out and measuring medicines.

2. Class II or "Hospital attendants" were men who would have had about a three years' training, at the end of which time they should be fit to receive a certificate saying that they knew the work of an orderly in hospital wards, including the taking of temperature, pulse and respiration, the elements of dispensing, the practice of vaccination, the preparation and sterilisation of surgical dressings and the dressing of wounds according to aseptic principles. When a man had reached this proficiency he could either get employment in Nyasaland or in South Africa, or he could continue his training and enter Class III. For the training of Class II a systematic course was proposed. The Blantyre course included the following:

First Year. The general structure of the body. The treatment of wounds, ulcers, burns. Bandaging.

Second Year. Temperature taking, the elements of dispensing. Weights and measures. The different syringes and their uses. Baths and packs, cupping, poultices, fomentations. The care of patients. Disinfection.

Third Year. How to observe patients, the pulse, etcetera. States of collapse, concussion, delirium, etcetera. What to do in emergencies, drowning, poisoning, snake bites, loss of blood. Contagions and infection. These divisions were more or less arbitrary.

3. Class III were "Medical assistants" who would take a further course that would enable them to take an important post at the main hospital, or be put in charge of a medical out-station, or to be at a European Station where there was no Doctor. Medical assistants acted a great deal on their own initiative with the medical man over them some distance away. Dr. Caverhill advised that where there was more than one hospital, for the sake of economy of materials and time, it would be advisable for men to be sent in to one central hospital for this higher course.

For the training of Class III an advanced course of lectures was necessary, as well as practical work, more advanced than the former and, which included the symptoms and treatment of the commoner diseases of the country, anaesthetics, fractures, first-aid, the actions of medicines and minor surgical operations. ${ }^{5}$

The men who were chosen for training should have been to school for three or four years at least, and they should start hospital work because they wanted to and not because they had been tried at everything else and had failed. Reliability was regarded as important qualification as it was a "sine qua non in medical word".6

Dr. Caverhill's ideal was that every main station should have a hospital with a doctor and nurse or nurses, with men in it who were being trained as hospital attendants. The outlying districts would be served by men who had been trained as medical assistants at one central school where the "cream" of the hospital attendants could be sent for this further training. Dr. Caverhill stressed the fact that the missions could not hope to supply the medical needs of Africa by their own individual efforts any more than they could evangelise it. Co-operation was necessary. ${ }^{7}$

Miss Dewar of the Blantyre Mission talked about the possibility of training African women as nurses during this 1904 Conference. She said that since the 1900 Conference, the girls proved to them that: "their intellects are as keen, and their grasp of the subject taught them is as clear as that of the boys".

She stressed the importance of a sound education before nurse training could commence and said: "The idea is still abroad that a nurse is born not made, but while even in the rawest native women we may find some of the qualities which go to make a good nurse, until she is possessed of a good education she is incompetent of grasping the most elementary part of the preliminary training. "9

The D.R.C. Mission started early with boarding schools for girls, 1895, and therefore when the Mission was eventually equipped with the necessary medical staff and facilities, women candidates in possession of an acceptable educational standard were available for nurse training During 1908 Dr. W.A. Murray started with the training of midwives at Mvera, one of whom was Sarah Nabanda.

Unfortunately training was not consistent because of a shortage of Mission personnel, and funds.

Sir Alfred Sharpe, Commissioner of the 
Protectorate, welcomed the idea of standardizing the training of African Nurses (male and female) and approved that they should be examined officially. $\mathrm{He}$ suggested that a small board be formed, consisting of the Principal Medical Officer, another Government Doctor and any two Mission doctors. This board should consider practicable schemes for the evaluation of students. Certificates would also be issued. Such a Medical Board was formed during 1905, consisting of Government and Mission representatives to plan for training courses and arrange for examinations. 10

The two Scottish Missions took the lead in the training of male orderlies and assistants. During 1909 the Government had approved of the training course for hospital orderlies and assistants at the Blantyre Hospital. Their candidates were then officially examined."

During 1909 the Henry Henderson Institute, the Educational Institution at the Blantyre Mission, came into being and the medical course became even more refined.

A third General Mission Conference was held at Mvera during 1910 . During this conference the Educational Code was further revised and it was dediced to substitute the courses drawn up and used by Dr. Caverhill at the Blantyre Hospital for the course suggested in 1905. These courses which included courses for training of Hospital Orderlies, Hospital Assistants and Ward Girls were outlined and copies were handed out to the conference members. These courses were then printed in the Handbook of the Henry Henderson Institute, Blantyre pp. 13-14. A copy of the previous examination paper for Hospital Orderlies was also included. The courses for hospital orderlies and assistants had then been incorporated into the Nyasaland Educational Code. ${ }^{12}$

The Government had accepted a standard of training for hospital orderlies and hospital assistants and had arranged for conjoint examinations and granted certificates along with the medical training institute. The Government was willing to employ as many Africans as the Mission could manage to train. They offered to pay hospital orderlies from ten shillings to one pound and hospital assistants from one pound ten shillings to three pounds per month.

Dr. Caverhill was of the opinion that the Missions had a duty to supply the Government with trained African nurses. He said: "for the Government has a right to look to us to supply Natives skilled in medical and public health work and also to influence the community favourably towards sanitary reform." 33 By 1910 the Missions had not done much to fill Government posts. At the Blantyre Mission hospital one African had passed as hospital orderly and five were in training. They had planned to have twelve orderlies in training, with three or four qualifying per year. That would not leave a large surplus of orderlies to enter Government service, so they had to review the matter. With regard to the hospital assistants, which was an advanced course for only a few chosen male students, Dr. Caverhill suggested that there should be only one intake every four years. Such a source should only be given at a few centres as was feasible in the country. The centres should draw their students from throughout the whole country in order that the needs of all districts might be met. ${ }^{14}$

The Blantyre Mission hospital became one of the centres where hospital assistants were trained. Dr. A.M. Caverhill was in charge of the training till he left, and from 1920 Dr. Wilfred McFarlane took over. During 1913 the Government agreed that the course for training hospital assistants would be four years with a further year working on the staff of the training school. As there were more applicants than places available, the entrance was by competitive examination. This training course had a very good reputation and the trainees came from all parts of the country. After qualifying they obtained posts in Nyasaland, Northern and Southern Rhodesia and Tanganyika. The Livingstonia Mission as well as the Universities Mission to Central Africa trained hospital orderlies and assistants. ${ }^{15}$

The D.R.C. Mission trained hospital orderlies and midwives during this period but not medical assistants. The training was continued at Mkhoma hospital after 1913 when the headquarters of the Mission was moved from Mvera to Mkhoma. During 1914 the Executive Mission Council reported that they considered the training of African midwives for the outstations at Mkhoma as very important and desirable. ${ }^{\text {th }}$ Unfortunately no statistics of trainees were kept.

The education system began to develop steadily but then 1914-1918 war came. Many Africans and missionaries were called up for military service which caused much disruption of their work and all the Missions suffered a severe setback.

The years 1919 to 1925 were years of recovery. The education was stimulated by the visit of the Phelps-Stokes Commission during 1924 which recommended a policy of co-operation between Government and Missions in education. ${ }^{17}$

During 1924 a fourth General Missionary Conference was held at Livingstonia. One whole day was spent on the discussions of medical work, mostly training and the recommendations of the Phelps-Stokes Commission.

Dr. Laws. of the Livingstonia Mission, explained that Government recognition for trained medical assistants was needed both to give them status and to limit their sphere of work and responsibility. He advocated that, as in Scotland, there should be a Medical Council to set curricula and examinations, and thereby protect the public from fraud. Dr. Laws said the following about a Government and Mission effort to get recognition for African sub-assistants. "When the register for sub-assistant surgeons was passed by the Legislative Council, it was agreed to, under the promise by Government that other registers and recognition of African sub-assistants would be added. Much care and attention was given to this by a
Committee of Government and Mission Doctors, appointed by H.E. the Governor who deeply sympathised with the movement. Though the bill was ready, the War prevented its being brought into the Legislative Council, but we hope the original bill, or that modified, will yet be carried through."18

During this Fourth Conference Miss Isa Murray of Mkhoma delivered a paper on "Christian Women's Vocation as a Nurse". Nurse Murray had experience in the training of midwives and talked with authority about her experiences.

She strongly recommended that the Missions should train married women with children as midwives. Her experience had been that such women were more respected in the village, their husbands protected them and they were not jealous of the other women's happiness. An evangelist also advised her accordingly. She found that young girls who had spent some years as boarders on the station and who had passed standards I and II found it easier to grasp the book knowledge required and do the hospital work. On the other hanc they wanted responsible married women to practise midwifery and village work. Miss Murray therefore suggested that senior boarders who were ready to undertake training, should be taken on as

probationers and be trained for a year or longer. They then would probably marry and would be unwilling to stay longer, but after they had been settled in their homes for a couple of years they could return for further training in midwifery. That did not imply that they needed to neglect their husbands and families. They could live near the hospital and come in for daily instruction and attend cases at the villages with the missionary nurse. ${ }^{19}$ This remained the policy of the Missions during this period discussed, to only train married women as midwives, as they were more acceptable to their communities.

\section{THE PERIOD 1926 AND ONWARDS}

During 1926, the Missions held their Fin

General Conference in Blantyre. Mr. R.F. Gaunt, the Director of Education, attended during the two days when education was discussed 20

A Department of Education was formed during 1926. Vocational schools, which included theological schools, trade and normal schools (teacher training) and schools where medical assistants and dispensers were trained, were under the control of the Department of Education. African men who wished to be trained as medical assistants and dispensers could register for these courses after completion of the Upper Middle School courses. Upper Middle Schools were only run at Mission stations under the supervision of Missionary teachers and children were taught through the medium of English from Standard IV to VI. The courses for medical assistants was four years and was run by the Livingstonia and Blantyre Missions. (The less advanced courses for Dispensers and Dressers were implemented at Blantyre and by the Government at Zomba.) After completion of the medical 
assistant course the candidates were employed by the Missions and by the Government to work in village

dispensaries. ${ }^{2}$

During 1926 a Medical Council was formed. The Council laid down the standards of courses and examinations. During the first meeting of the Medical Council in July 1926, the Council decided that, with reference to the registration of Hospital Assistants under Section 18 of the Medical Practitioners and Dentists Ordinance, No. 6 of 1926, a syllabus could then act as a guide to the training schools. The syllabus was prepared during the second meeting of the Council during February 1927 by the members of the Council. ${ }^{22}$

The Government agreed to the registration of Medical Assistants during 1926. Section 18 of the Medical Practitioners and Dentists Ordinance, No. 6 of 1926, made provision for a subregister to be kept for the registration of medical assistants. This permission,

ranted by the Government, gave well hed Africans standing in their own country and was gladly welcomed by the Missions. During the second meeting of the Medical Council in February 1927 there were two applicants for registration on the Sub-Register for Medical Assistants. James Msisha of the Livingstonia Mission and Herbert Nyirenda of the Government Medical Department. The Council then decided to submit the following names of hospital assistants employed by the Government Medical Department: Daniel Gondwe, Thomas Cheonga and Moses Kaundy. ${ }^{23}$

During the 1926 General Missionary Conference the Livingstonia staff submitted a scheme for the training of female nurses. For all these courses a high standard of character and education was essential. ${ }^{24}$

The Missions felt that the training of medical personnel was one of their best

cmetributions to the medical services and

ulation of the country. They not only trained men and women to be able to provide medical care, but training of the character was seen as part of the training programme.

After explaining the syllabus of the Blantyre Hospital of the different categories of nurses, Dr. Caverhill said: “... and by far the most important bit is left out, namely, the training of the boys' characters. A good knowledge of the above is not of much service if he cannot be trusted to be attentive to a sick native, and at least to try and keep awake at nights. "2s

The Missionaries saw the Christian African nurse as part of the team for spreading the Gospel. Dr. Caverhill spoke for the other Missions when he said: "... by the placing of hospitals at important centres, and the training of boys for outstation work, the needless suffering of the native may be relieved and at the same time the evangelisation of Africa will be speedily hastened." 26

During the fourth General Missionary Conference, 1924, the Rev. Dr. Laws of Livingstonia said the following on this subject: "We seek first and foremost to have our students selected from Christian lads who will choose this work that they may follow in the footsteps of our Lord, the first and greatest of Medical Missionaries, and filled with love and compassion to their fellow men, who will seek not only the healing of the bodies of their patients, but to lead them to the Saviour, of Whom their sympathy, help and constant patient tenderness should speak." He continued to say: "There is a team connection in this work also, where doctor, nurses, and students can show a united front of self-denial, mutual consideration, helpfulness and devotion to Christ; then that focus of human suffering called a hospital, can and does become a focus of light shining from the Cross of Christ to enlighten all coming within its influence." 27

The same characteristics of honesty, compassion and love were expected of the Christian lady nurse. Miss 1.B. Murray of the Mkhoma Mission said: "We want healthy, intelligent Christian women with some education. Sympathetic and willing to serve strangers even if they are ungrateful. Of good family if possible, because they will have more authority in dealing with patients. Clean in their habits, observant, obedient and having a capacity for accurate statement they will be sent to see patients at a village and must be able to bring a reliable report to the doctor. ${ }^{2} \mathrm{k}$

It is therefore obvious that the category of nurses trained by the Missions was not only medically trained but of sound Christian character. Therefore the medical corps of the country were people respected by both Europeans and Africans and helped to render a good health service.

\section{SUMMARY}

In the beginning the Missions were solely responsible for the educational and nursing training in the country. Although they worked independently they tried to standardise training by holding regular conferences. During 1905, on such a conference, a Medical Board was formed with mission and government

representation to maintain the standard of nurse training.

The Missions acted as a pressure group and by 1926 persuaded the Government to establish a Department of Education and subsequently a Medical Council. One of the functions of the Council was to set the Examinations, compile a syllabus and issue certificates and thereby the standard of nursing was raised. Legislation was provided whereby medical assistants could register on a sub-register to the Medical Practitioners and Dentists Ordinance of 1926, and thus their status were upgraded.
The nurses (males and females) chosen for nursing were predominantly Christians and therefore the nursing corps were respected by all the peoples in the country.

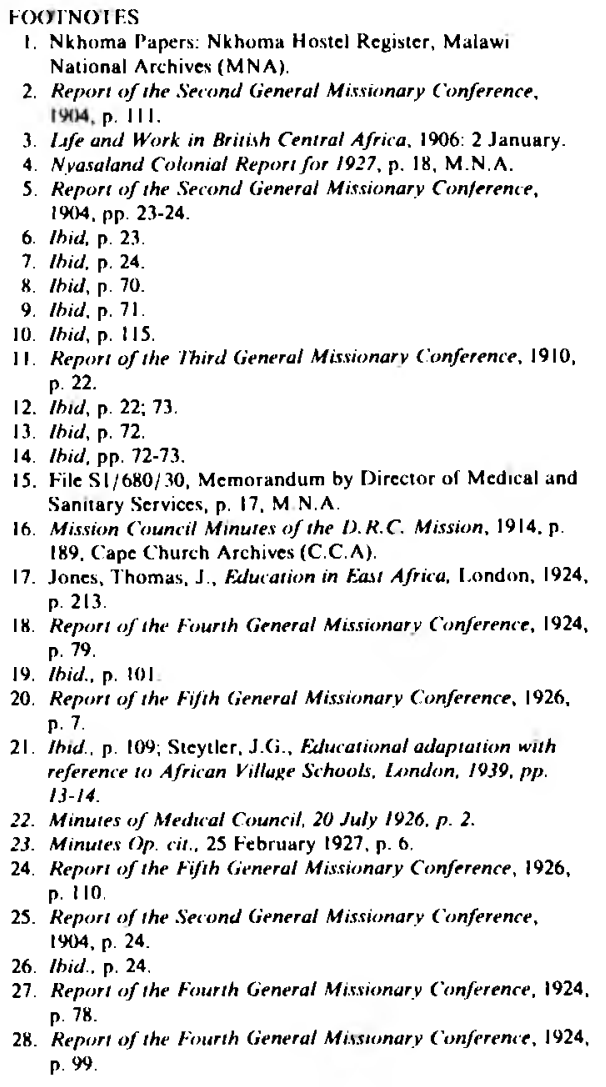

\section{BIBI.IOGRAPHY}

Books and Reports

1. Jones, Т.J. Education in East Africa, (Report on the Phelps-Stokes Commission), London, 1924.

2. Steytler, J.G. Educational adaptation with reference to African village schools, London. 1939.

3. Stcytler, J.G. Report of the Second General Missionary Conference. Blantyre, 1904.

4. Report of the Third General Missionary Conference, Blantyre, 1914.

5. Report of the Fourth General Missionary Conference, livingstonia, 1924.

6. Report of the Fifth General Missionary Conference, livingstonia, 1926. Archival Records

7. Archives of the I Dutch Reformed Church, Cape Town. Minutes of meetings: File S5 15/6/1/1: Mission Council Minutes, 1898-1928

8. Malawi National Archives, Zomba. Nyasaland Colonial Report, 1927.

9. Nkhoma Mission Church Papers: Nkhoma Hostel Register, 1913.

10. File S1/680/30: Memorandum by Director of Medical and Sanitary Services, 1929.

Joyce Smit

M. Nursing, Hons B A. Public Admin.

B. Cur. (l et $A$ )

Senior lecturer

Department of Nursing

University of Stellenbosch 